\title{
MEDIA TELEVISI DI ERA INTERNET
}

\author{
Aceng Abdullah ${ }^{1}$, Lilis Puspitasari $^{1}$ \\ ${ }^{1}$ Universitas Padjadjaran
}

\begin{abstract}
ABSTRAK
Televisi sebagai media massa yang hampir satu abad menjadi media massa paling disukai saat ini mulai terganggu (disrupted) oleh kehadiran media baru, yakni media sosial. Media baru ini semakin berkembang di Tanah Air yang menjadikan Indonesia sebagai salah satu negara pengguna internet tertinggi di dunia. Hampir setengah dari penduduk Indonesia saat ini menjadi pengguna internet, mereka mengakses internet umumnya dari telepon pintar atau smartphone. Khalayak media massa Indonesia pun (khususnya generasi muda) sekarang sudah beralih dalam penggunaan media, bukan hanya media cetak yang semakin tidak laku, tetapi juga mempengaruhi media televisi. Pola menonton TV pun telah berubah. Penonton tidak sepenuhnya terpaku oleh jam siaran dan waktu siaran. Di era internet orang bisa menonton TV kapan saja dan dimana saja. Selain itu, menonton acara TV pun tidak harus selalu dari pesawat televisi, tetapi banyak penonton, khususnya generasi milenial yang menonton melalui gadget, smartphone atau laptop. Siaran Televisi pun saat ini diatur dan diawasi dengan sangat ketat oleh pemerintah melalui Komisi Penyiaran Indonesia, tetapi media sosial terlihat masih sangat bebas karena belum adanya peraturan yang spesifik. Penonton bisa menonton apa saja termasuk tontonan yang sangat dilarang untuk disiarkan di televisi, melalui media sosial sebuah tontonan terlarang dengan sangat mudah dan bebas dapat ditonton oleh siapa saja.
\end{abstract}

Kata-kata Kunci: Televisi, Media Sosial, Internet.

\section{TELEVISION MEDIA IN THE INTERNET ERA}

\begin{abstract}
Television as a mass media which is almost in a century became the most preferred mass media at this time began to be disrupted by the presence of new media, namely social media. This new media is growing in the country which makes Indonesia one of the highest internet users in the world. Nearly half of Indonesia's population is currently an internet user, they access the internet generally from smart phones or smartphones. Indonesian mass media audiences (especially the younger generation) have now switched to the use of media, not only the print media that are increasingly unsold, but also affect television media. The pattern of watching TV has changed. The audience is not completely transfixed by the broadcast hours and broadcast time. In the internet era, people can watch TV anytime and anywhere. In addition, watching TV shows does not always have to be from a television set, but many viewers, especially millennials who watch through gadgets, smartphones or laptops. Television broadcasting is currently strictly regulated and supervised by the government through the Indonesian Broadcasting Commission, but social media is still very free because there are no specific regulations. The audience can watch anything including spectacle which is strictly prohibited to be broadcast on television, through social media a prohibited spectacle is very easy and free to be watched by anyone.
\end{abstract}

Keywords: Television, Social Media, Internet.

Korespondensi: Aceng Abdullah. Universitas Padjadjaran, J1. Raya Bandung-Sumedang KM. 21. Email: acengabd@yahoo.com 


\section{PENDAHULUAN}

Selama puluhan tahun televisi sebagai media massa merupakan media yang paling digemari sebagai media hiburan dan informasi. Karena sifatnya yang audio visual, televisi dapat menghadirkan acara musik, film, sinetron, variety show, reality show serta acara lainnya dengan melibatkan para selebritis idola khalayak. Begitu pun acara olahraga, orang dapat menonton aneka pertandingan olahraga tanpa harus berangkat ke stadion atau lokasi pertandingan. Juga siaran informasi yang sebelumnya dikategorikan acara yang tidak menarik, melalui televisi acara informasi baik siaran berita maupun info lainnya memiliki pesona tersendiri terlebih televisi dapat menyiarkan secara langsung dari lokasi kejadian.

Karena itulah di Indonesia selama puluhan tahun, bahkan di negeri asalnya hampir satu abad siaran televisi menjadi media yang paling banyak penontonnya. Karena itulah televisi dijadikan media promosi utama oleh dunia industri untuk memasarkan produk barang dan jasa mereka.

Namun, lambat laun kedigdayaan televisi seolah terganggu (disrupted) oleh media baru bernama media sosial sebagai turunan dari perkembangan teknologi internet. Pengguna internet pun semakin tinggi sejalan dengan perkembangan teknologi telepon selular yang berhasil menciptakan telepon pintar (smartphone) yang harganya jauh lebih murah daripada PC atau laptop sebagai sarana untuk mengakses internet. Lebih mencengangkan lagi, Indonesia yang dikategorikan bukan sebagai negara maju, ternyata juga menjadi negara pengguna internet yang tinggi di dunia.

Kendati dikategorikan sebagai negara berkembang dengan penguasaan ilmu dan teknologi yang dinilai masih cukup rendah, ternyata Indonesia menjadi negara pengguna internet nomor empat terbesar di dunia. Data tahun 2017 menyebutkan bahwa lebih dari 50\% penduduk Indonesia telah melek internet. Pengguna internet di Indonesia ini menurut Kantor Menteri Komunikasi dan Informatika mencapai 147 juta jiwa. Pengguna internet ini pun melonjak drastis lebih dari 20 juta pertahun sejak 2015, hal ini dipertajam dengan semakin meluasnya penggunaan telepon pintar (smartphone) yang makin digemari sehingga hampir semua pengguna internet di Indonesia adalah pengguna smartphone.

Makin besarnya pengguna internet yang sekaligus pengguna media sosial ini telah berperanguh terhadap pola penggunaan media massa. Media yang paling terdahulu merasakan dampak makin berkembangnya internet ini adalah media cetak. Terbukti, tiras media cetak terus menurun sejak awal tahun 2000-an. Tahun 2009 belasan media cetak di AS dan Eropa yang berusia ratusan tahun menyatakan berhenti terbit.

Media massa elektronik seperti TV yang diakses secara gratis, ternyata jumlah penontonnya juga makin menurun. Padahal selama ini media televisi merupakan media yang paling banyak diakses oleh khalayak di hampir seluruh penjuru dunia termasuk di Indonesia. Itu sebabnya raihan iklan TV di Indonesia hingga kini masih tetap yang terbesar 
bahkan masih merajai sebagai media massa yang meraup kue iklan terbesar di negeri kita pada tahun 2018 dengan nilai sekitar Rp 115,8 triliun yang tersebar di 15 stasiun televisi nasional, atau meraup $80 \%$ dari total belanja iklan untuk semua media ${ }^{1}$.

Namun dengan munculnya fenomena baru dalam perubahan penggunaan media ini banyak pihak yang meramalkan bahwa suatu ketika TV akan makin ditinggalkan oleh pemirsanya. Meski demikian, banyak pula para ahli yang merasa optimis bahwa media televisi tidak akan sepenuhnya mati karena berbagai kelebihannya.

Semenjak telepon pintar (smartphone) yang berbasis internet membanjiri pasaran dan digemari oleh banyak orang, media sosial pun menjadi kebutuhan banyak orang, bahkan informasi yang berasal dari media-online kebanyakan dibuka melalui link di media sosial ini. Media massa arus utama pun mulai "terganggu" (disrupted) oleh media baru ini. Fungsi media massa mulai digoyahkan oleh media sosial yang segalanya dapat diakses melalui smartphone ini. Fungsi informasi dan hiburan dari media massa mulai direbut oleh media sosial ini. Inilah salah satu penyebab terganggunya lembaga media massa arus utama ini.

Berdasarkan latar belakang masalah di atas muncul pertanyaan:

1. Bagaimana eksistensi TV di era internet
2. Bagaimana pola baru menonton televisi di kalangan khalayak remaja.

3. Bagaimana pula tentang regulasi yang dibuat pemerintah tentang media baru ini di tengah tingginya pengguna internet serta kompleksnya konten media sosial saat ini.

\section{METODE PENELITIAN}

Artikel ini akan memaparkan dan membahas tentang berbagai hal tersebut dengan metode deskriptif. Pengumpulan data dilakukan melalui, wawancara, observasi dan studi referensi. Wawancara dilakukan terhadap sejumlah remaja di kota Bandung dan Kab. Garut. Kota Bandung dipilih karena dinilai mempresentasikan kota metropolitan dengan segala gaya hidupnya, dan Kab. Garut dipilih sebagai daerah rural tetapi warganya sudah melek teknologi internet.

Observasi dilakukan sejak Januari sampai dengan Juni 2018 terhadap semua stasiun TV yang bersiaran secara nasional serta beberapa TV Lokal di Bandung khususnya program acara yang disiarkan pada waktu utama (prime time). Studi referensi digunakan untuk melengkapi data serta tinjauan teoritis lainnya. Bahan referensi diambil dari berbagai sumber seperti buku, artikel atau berita baik di media konvensional maupun dari internet.

\footnotetext{
${ }^{1}$ http://marketeers.com/belanja-iklan-diindonesia-memang-naik-tapil
} 


\section{HASIL DAN PEMBAHASAN}

\section{Eksistensi Televisi di Indonesia}

Sekitar satu abad televisi siaran menjadi primadona dalam percaturan media komunikasi massa. Sejak ditemukannya media ini di sekitar 1900-an, televisi popularitasnya langsung melejit bahkan saat itu diramalkan, TV akan mematikan radio siaran sebagai media komunikasi massa karena sifat televisi yang audio visual.

Penemuan teknologi televisi ini mendorong lahirnya sejumlah stasiun TV di berbagai Negara, seperti di Inggris pada 1936 berdiri BBC (British Broadcasting Corporation). Lima tahun kemudian di Amerika tepatnya pada 1941 berdiri Columbia Broadcasting System (CBS) yang memulai siaran telvisi setelah sebelumnya CBS ini merupakan korporasi media radio sejak 1927. Kemudian berdiri pula NBC (National Broadcasting Company), dan mulai 1943 berdiri ABC (American Broadcasting Company $)^{2}$

Selain dinilai akan membunuh radio, televisi juga dulu diramalkan akan mematikan bioskop, karena menonton bioskop tidak perlu lagi datang ke gedung bioskop tetapi cukup menonton di rumah.

Televisi semakin melejit tatkala teknologinya semakin maju dimana dari hitam putih menjadi berwarna. Khalayak penonton TV pun makin luas, termasuk di Indonesia yang pada 24 Agustus 1962 mulai memiliki stasiun
MEDIA TELEVISI DI ERA INTERNET TVRI, stasiun pertama di Indonesia yang didirikan dalam rangka penyelenggaraan Asian Games 1962 di Jakarta.

Fungsi televisi pun semakin luas, yang pada awalnya hanya sebagai media hiburan kemudian melebar memiliki fungsi informasi dan edukasi. Mulai dekade 70-an di Indonesia TV siaran menjadi industri media massa karena industri barang dan jasa sudah mulai mempromosikan produknya melalui TV ini, dan media audio visual ini pun dianggap media massa paling efektif dibanding media massa lainnya karena lebih atraktif dan pesawat TV ini dimiliki oleh sebagian besar rumah tangga.

Mulai era 70-an di negara-negara maju stasiun TV bersaing ketat, sementara di Indonesia saat itu siaran TV masih dimonopoli oleh TVRI sebagai lembaga siaran milik pemerintah. Televisi swasta di era Orde Baru belum diijinkan untuk berdiri di Indonesia, pertimbangannya amat politis karena TV dianggap memiliki daya pengaruh yang tinggi terhadap khalayaknya. TVRI di masa Orde Baru lalu digunakan sebagai media propaganda pemerintah dengan dalih sebagai media komunikasi pembangunan serta untuk menjaga stabilitas nasional.

Televisi swasta baru dapat berdiri di Indonesia setelah pemohon ijinnya adalah putra putri serta kerabat dekat Presiden Soeharto sendiri. $R C T I$ adalah stasiun TV swasta pertama milik Bambang Trihatmojo, putra sulung Soeharto. Kemudian ada SCTV milik

\footnotetext{
${ }^{2}$ Ibrahim dan Iriantara, 2017, Komunikasi yang

Mengubah Dunia, Simbiosa Rekatama Media, Bandung
} 
konglomerat Soedwikatmono, kerabat dekat Soeharto juga. Putri sulung Soeharto, Mbak Tutut (Siti Haditanti Rukmana) mendirikan TPI dan konglomerat yang amat dekat dengan Istana Orde Baru, Sudono Salim diijinkan untuk membuka Indosiar, semuanya berdiri di era 80an. Setelah itu bermunculan stasiun TV swasta lainnya.

Karena sifatnya yang audio visual, televisi menjadi media massa primadona yang digemari banyak orang. Selain siarannya gratis -kendati ada pula televisi berbayar- siaran televisi masa kini hampir 24 jam bersiaran nonstop. Selain hiburan film, sinetron, reality dan variety show, juga musik, melalui televisi juga jutaan orang pencinta sepakbola atau olahraga lainnya bisa menikmati aneka pertandingan, baik pertandingan yang sudah lewat maupun siaran langsung.

Dari fungsi informasi, televisi juga menjadi media yang lebih atraktif dan lebih aktual dibanding media cetak dalam menyiarkan informasi yang terjadi. Jika media cetak baru akan menyiarkan berita esok paginya, televisi bisa memberitakan sore atau malam harinya, bahkan siaran langsung di tempat kejadian sehingga aktualitas televisi lebih unggul dibanding media cetak. Hampir semua stasiun TV memiliki acara siaran berita yang dikemas dengan sangat menarik.

Kelemahan siaran televisi yang dinilai dengan sifatnya yang selintas dan tidak mendalam dalam menyiarkan informasi, saat ini sudah tidak berlaku lagi karena dalam acara siaran berita hampir setiap malam di TV tertentu ada talkshow atau wawancara khusus yang secara mendalam menggali permasalahan hingga tuntas, bahkan perdebatan terbuka antara dua kubu yang berseberangan pun sekarang menjadi tontonan hiburan tersendiri.

\section{Pola Baru Menonton Televisi di Era Internet}

Teknologi internet ikut mempengaruhi terhadap perkembangan pertelevisian baik di tingkat nasional maupun global. Pada bagianbagian tertentu teknologi baru ini berdampak secara positif, tetapi teknologi internet ini juga sekaligus memiliki dampak negatif ditinjau dari aspek televisi sebagai industri atau sebagai institusi bisnis. Bahkan beberapa kebijakan yang berkaitan penerapan teknologi internet ini justru menjadi buah simalakama.

Aspek positif penerapan teknologi internet sangat membantu dalam aspek televisi sebagai fungsi informasi. Dalam produksi berita atau informasi, khalayak sangat diuntungkan karena segala informasi dapat disajikan dengan sangat aktual. Berita saat ini bisa disiarkan saat ini juga berkat bantuan internet. Hal ini amat sangat jauh berbeda di era sebelum internet dikenal dalam industri media. Pengiriman berita termasuk gambar video dapat dikirimkan secara cepat dengan biaya yang relatif murah dibanding di masa lalu. Bahkan reporter pun dapat secara live dari tempat kejadian melaporkan sebuah peristiwa. Pendek kata dalam urusan reportase di lapangan, teknologi internet ini sangat membantu. Dengan demikian kualitas acara informasi jauh lebih baik dibanding televisi di masa lalu.

Begitu pun dalam aspek penyiarannya, berkat teknologi streaming, sebuah siaran tidak dibatasi lagi oleh sekat-sekat kewilayahaan. 
Orang Indonesia yang tinggal di mana pun di seluruh penjuru dunia, dengan mudah dapat mengikuti berbagai acara televisi melalui streaming dan ditonton melalui laptop atau smartphone-nya. Pertandingan Persib atau berita bencana alam di berbagai pelosok Tanah Air bisa dengan mudah ditonton dari mana saja.

Aneka program acara tertentu, terkadang juga dapat ditonton melalui media Youtube. Sejumlah stasiun TV yang menerapkan konsep multi platform acapkali menampilkan kembali berbagai acara andalannya di Youtube ini sehingga jangkauan dan jumlah penonton sebuah acara makin luas lagi. Orang yang tidak mengikuti sebuah acara pada waktunya, bisa menontonnya di lain waktu melalui layar Youtube ini.

Karena perubahan di atas, pola menonton TV pun juga ikut berubah, terlebih bagi khalayak yang menjadikan internet bagian hidupnya, dalam hal ini generasi milenial yang hampir 24 jam tidak lepas dari genggaman smartphone. Namun ada juga yang berpendapat, perubahan yang dilakukan oleh pihak televisi justru karena perubahan budaya yang terjadi pada khalayak televisi, khususnya kaum milenial ini.

"Saya sudah tidak terpaku dengan jadwal acara di televisi. Waktu dulu bisa duduk lama di hadapan layar TV untuk menonton sebuah acara. Sekarang mah tidak sesuai jadwal karena acara yang sama dapat pula ditonton di Youtube. Jaman sekarang mah gak perlu takut

\footnotetext{
${ }^{3}$ Wawancara dengan Hilda Rahma Selvia, siswi SMAN 1 Garut.

${ }^{4}$ Biagi, Shirley, (1990), Media Impact, An Introduction to Mass Media, California Stae Universitu,
}

ketinggalan acara". (wawancara Hilda Rahma Selvia) ${ }^{3}$

Saat ini sudah terjadi perubahan dalam pola menonton TV. Generasi milenial sudah jarang yang duduk berjam-jam di hadapan layar TV untuk mengikuti sebuah acara. Padahal di masa kejayaannya TV menjadi media massa yang paling banyak dikritik dan disorot karena TV dinilai telah memepengaruhi mental khalayak khususnya generasi muda dan anakanak.

Anak-anak dan remaja di era '70 dan '80an selalu menjadi obyek penelitian para ilmuwan komunikasi karena mereka setiap minggunya bisa menghabiskan waktu berjamjam di hadapan layar TV. Dampak negatif televisi terhadap anak-anak dari sebuah penelitian di AS pada era '80-an adalah munculnya perilaku agresif dan berfantasi, khususnya bagi mereka yang selalu menonton film-film action. ${ }^{4}$

"Sekarang mah aku dan juga temanteman $u d a h$ jarang nonton TV. Paling kalau kebetulan saja pas ke ruang TV ada film atau acara bagus baru nimbrung nonton. Temen-temen aku juga sama. Tapi ya ga anti juga karena masih ada acara-acara bagus dan menarik buat ditonton. Pokoknya mah ga pernah nyengajain untuk nonton. Nonton di HP aja di kamar" 5

\section{Media Sosial sebagai Media Televisi}

Media sosial dari hari ke hari penggunanya terus bertambah. Makin berkembangnya jumlah pengguna media sosial

\footnotetext{
Wadsworth Publishing Company.

${ }^{5}$ Wawancara dengan Sherly Purnama Sari, siswa SMAN 8 Bandung.
} 
ini berpengaruh terhadap perkembangan media massa termasuk media televisi. Jumlah penonton acara televisi diperkirakan penontonnya tidak berkurang, tetapi penontonnya tidak menonton pada waktu yang bersamaan pada kanal tersebut melalui layar $\mathrm{TV}$, tetapi menonton melalui jalur lain, yakni menonton melalui Youtube atau televisi berlangganan yang bisa memutar ulang sebuah siaran untuk ditonton di waktu yang lain sampai beberapa hari ke depan. Akibatnya angka rating penonton yang diukur pada saat orang menonton di stasiun TV tertentu, angkanya menjadi berkurang.

Selain itu, menonton sebuah acara TV pun sekarang dapat dilakukan melalui smartphone secara streaming kapan saja dan dimana saja. Hal ini tentu saja mengaburkan hasil riset lembaga pembuat rating yang kabarnya mengukur jumlah penonton sebuah acara melalui alat yang dipasang di rumah responden. Karena jumlah penontonnya berkurang, ratingnya juga ikut turun sehingga mempengaruhi pemasang iklan yang berpatokan kepada jumlah penonton sebuah acara. Abrahamson (2017) dalam tulisannya berjudul Social Media Is the New Television memaparkan bahwa saat ini media sosial menjadi televisi baru bagi khalayaknya khususnya kaum muda ${ }^{6}$. Menurutnya, kaum muda sudah mulai menjauhi layar televisi. Mereka berganti layar ke layar smartphone.

B. $6 \quad$ https://www.adweek.com/digital/kurtabrahamson-sharethis-guest-post-social-media-isthe-new-television/
Rating acara Academy Award 2017 yang disiarkan sebuah stasiun TV di AS menurun dengan angka paling rendah dalam sembilan tahun terakhir ini. Jumlah penontonnya menurun sekitar $4,4 \%$ dibanding penonton acara yang sama tahun sebelumnya.

Perhatian penonton, papar Abrahamson semakin menjauhi layar televisi dan terus bergerak menuju perangkat seluler dan media sosial. Mengutip Insight Tubular, 87\% generasi milenial di Amerika menggunakan smartphone dan $92 \%$ dari mereka menjelajah di perangkat lain saat menonton program TV. Mereka sering menggunakan perangkat layar kedua untuk menghabiskan waktu di jejaring sosial, mengobrol tentang konten yang mereka tonton atau terlibat dengan konten yang berbeda. Meskipun demikian, Abrahamson yakin, pesawat TV tidak akan sepenuhnya ditinggalkan pemirsanya. Anggapan bahwa TV akan mati menurutnya merupakan anggapan yang berlebihan.

Fenomena serupa diberitakan oleh CNN Indonesia (09/05/2018) yang menyatakan, jumlah netizen Indonesia yang menonton YouTube_hampir menyaingi jumlah netizen yang menonton televisi. Hal ini terungkap dari Survei Google dan Kantor TNS pada Januari 2018. Menurut survei itu, YouTube ditonton oleh $53 \%$ pengguna internet di Indonesia. Sementara 57\% netizen juga menonton televisi. Berdasarkan survey tersebut 
membuat prime time menjadi lebih luas karena orang tidak perlu menunggu jam tayang di TV. Karena itu, pengiklan juga memiliki opsi kampanye yang lebih lama dan variatif seperti story telling, humor, atau engagment lainnya. ${ }^{7}$

HU Republika (13 Januari 2016) juga memberitakan popularitas smartphone dan tablet mampu melampaui televisi. Sebuah studi dari lembaga survei Nielsen Co menegaskan bahwa pengguna Smartphone telah melampui media televisi tradisional. Kecenderungan ini terutama, bagi pemirsa berusia 18-34 tahun. Dalam survei tahun 2016 itu, Nielsen menemukan bahwa penonton TV tradisional semua kelompok umur mencapai puncaknya pada kurun 2009-2010.

Sampai kurun waktu tersebut, penonton TV terus tumbuh setiap tahun sejak tahun 1949. Namun mulai 2011 angka penonton TV terus merosot. ${ }^{8}$

Kondisi seperti ini tentu saja akan berpengaruh terhadap dunia periklanan, seperti yang diungkapkan Sheldon $(2015)^{9}$ juga Narayanan dkk (2012) ${ }^{10}$ bahwa media sosial akan mempengaruhi sektor periklanan, termasuk iklan televisi karena penonton televisi akan berkurang serta iklan via media social yang jauh lebih murah ketimbang di media massa utama.

C.

https://www.cnnindonesia.com/teknologi/201805 09180435-185-297003/penonton-youtube-saingijumlah-netizen-yang-tonton-televisi 3/o0vsw59-nasib-televisi-di-era-internet
Melihat kenyataan tersebut, tidak berlebihan apabila banyak pengamat yang menyatakan bahwa media sosial saat ini menjadi media televisi baru bagi khalayaknya khususnya kaum milenial. Diantaranya Michael Wolff, yang menulis buku Television Is the New Television: The Unexpected Triumph of Old Media In the Digital Age.

\section{Etika dan Pedoman Siaran Televisi dan}

Medsos

Sejumlah buku tentang komunikasi massa dan juga banyak penelitian di berbagai penjuru dunia, televisi berpengaruh kuat terhadap khalayaknya. Tingkat keterpengaruhan ini pun tidak seragam dan sangat dipengaruhi unsur-unsur demografi khalayaknya, namun pengaruh TV sebagai media massa terlihat lebih signifikan ketimbang media massa lainnya, hal ini disebabkan karena terpaan televisi siaran jauh lebih besar daripada media lainnya karena sifat televisi yang hampir selalu ada di setiap rumah tangga, siarannya hampir 24 jam dan dapat diakses secara gratis. Penontonnya pun beragam dari mulai balita hingga orang lanjut usia. Karena itulah, penelitian dan pembahasan tentang televisi jauh lebih banyak daripada media massa lainnya.

Karena khalayaknya lebih banyak daripada media massa lainnya, maka TV pun menjadi ajang promosi dan kampanye untuk

\footnotetext{
${ }^{9}$ Sheldon, Pavica, 2015, Social Media, Principles and Applications. Lexington Books, Lanham

${ }^{10}$ Narayanan, M, Asur, etc, (2012), Social Media and Bussiness. Vikalpa: The Journal for the Decision Maker, 37 (4)
} 
berbagai kepentingan. Kalangan industri dan bisnis rela menggelontorkan dananya yang sangat besar untuk promosi melalui TV karena efektivitasnya telah dirasakan oleh pelaku bisnis. Produk dan jasa mereka setelah dipromosikan melalui layar TV penjualannya meningkat. Di lain pihak sesama stasiun TV juga bersaing untuk mendapatkan order iklan. Pilihan pengiklan tentu saja ditujukan kepada stasiun atau program acara yang paling banyak penontonnya sesuai hasil riset rating dari sebuah program acara. Itu sebabnya stasiun TV berusaha membuat acara semenarik mungkin agar dapat menyedot penonton sebanyakbanyaknya.

Acapkali berbagai cara dilakukan untuk menyedot jumlah penonton ini sehingga seringkali mengabaikan etika dan tanggungjawab sosial. Acapkali stasiun TV mengabaikan kualitas acara tetapi mengikuti selera pasar (khalayak), peduli amat apakah itu berkualitas atau tidak, memiliki nilai edukasi atau tidak, berpengaruh baik atau buruk, yang penting penontonnya banyak.

Karena seringkali terjadi pelanggaran, di hampir seluruh penjuru dunia dibuat peraturan yang ketat tentang siaran TV ini karena penonton TV tidak semuanya memahami literasi media, di samping anak-anak dan remaja juga perlu dilindungi dari perilaku pengiklan yang kerapkali melakukan promosi yang menyesatkan dari produk dan jasanya. Bahkan di negara liberal seperti Amerika ungkap

\footnotetext{
${ }^{11}$ Vonegut, Kurt, Jr, Cencorship and the First Amendment, in Biagi, Shirley, (1990), Media Impact,
}

Vonnegut (1990) ${ }^{11}$ para warganya dilindungi dari pengaruh buruk siaran televisi khususnya dari terpaan pornografi.

Di Indonesia Komisi Penyiaran Indonesia (KPI) membuat aturan yang sangat ketat berupa Pedoman Perilaku Penyiaran (P3) dan Standar Program Siaran (SPS) bagi lembaga penyiaran. Aturan ini untuk melindungi khalayak dari kemungkinan dampak buruk siaran TV.

Siaran Televisi begitu ketatnya diatur dan diawasi oleh lembaga bernama KPI (Komisi Penyiaran Indonesia) yang juga mewakili perwakilan di daerah bernama KPID. Aneka tayangan yang sekiranya dapat menimbulkan dampak negatif dilarang muncul di televisi.

Namun peraturan yang begitu ketat terhadap konten siaran TV nasional ini menjadi sia-sia ketika khalayak dengan mudahnya menonton konten tayangan video melalui media sosial. Semua tayangan yang dilarang muncul di televisi nasional seperti pornografi, kekerasan serta konten yang menghasut dan memprovokasi termasuk informasi yang menyesatkan dan mengadu-domba hampir setiap saat hadir dan ditonton dengan bebas dimana pun oleh pemegang smartphone termasuk oleh anak-anak dan remaja.

Pihak Kementerian Komunikasi dan Informatika (Menkominfo) kabarnya terus melakukan pemblokiran terhadap tayangantayangan negatif tersebut, namun derasnya informasi yang datang secara global itu hampir membuat aksi pemblokiran itu kewalahan. Oleh 
karena itu sudah saatnya pemerintah membuat regulasi lain baik ditujukan kepada operator media sosial maupun kepada semua rakyat Indonesia pengguna internet dan perangkatnya sebelum masa depan bangsa ini rusak.

\section{SIMPULAN}

a. Keberadaan televisi di era internet ini mulai terganggu (disrupted) oleh keberadaan media sosial. Media hiburan dan informasi bagi sebagian khalayak khususnya generasi milenial mulai mengandalkan media sosial untuk menggantikan dua fungsi media massa tersebut. Meskipun demikian para ahli komunikasi massa masih punya keyakinan bahwa TV tidak akan mati karena media sosial tidak memproduksi konten, tetapi hanya menyiarkan konten. Televisilah yang memproduksi konten tersebut.

b. Pola menonton TV pun telah berubah. Penonton tidak sepenuhnya terpaku oleh jam siaran dan waktu siaran. Di era internet orang bisa menonton TV kapan saja dan dimana saja. Selain itu, menonton acara TV pun tidak harus selalu dari pesawat televisi, tetapi banyak penonton, khususnya generasi milenial yang menonton melalui gadget, smartphone atau laptop.

c. Jika televisi konten siarannya diatur dan diawasi dengan sangat ketat, media sosial masih sangat bebas. Penonton bisa menonton apa saja termasuk tontonan yang sangat dilarang untuk disiarkan di televisi, melalui media sosial tontotan terlarang itu dengan sangat mudah dan bebas dapat ditonton oleh siapa saja.

\section{DAFTAR PUSTAKA}

Biagi, Shirley, (1990), Media Impact, An Introduction to Mass Media, California

State University, Wadsworth Publishing Company.

Ibrahim dan Iriantara, 2017, Komunikasi yang Mengubah Dunia, Simbiosa Rekatama Media, Bandung

Narayanan, M, Asur, etc, (2012), Social Media and Bussiness. Vikalpa: The Journal for the Decision Maker, 37 (4)

Sheldon, Pavica, 2015, Social Media, Principles and Applications. Lexington Books, Lanham

Vonegut, Kurt, Jr, Cencorship and the First Amendment, in Biagi, Shirley, (1990), Media Impact, An Introduction to Mass Media, California State University, Wadsworth Publishing Company

\section{Insternet}

http://marketeers.com/belanja-iklan-diindonesia-memang-naik-tapi/

https://www.adweek.com/digital/kurtabrahamson-sharethis-guest-post-socialmedia-is-the-new-television/ https://www.cnnindonesia.com/teknologi/2018 0509180435-185-297003/penontonyoutube-saingi-jumlah-netizen-yangtonton-televisi

https://www.republika.co.id/berita/koran/teraj u/16/01/13/o0vsw59-nasib-televisi-diera-internet 